\section{Archaeology and modern reflections on death}

Professionals working with patients at end of life need to feel comfortable and confident discussing death, dying and bereavement (DDB), however this is not always the case. $^{12}$

The Continuing Bonds Project sought to explore the impact of archaeology on the confidence and comfort for health and social care professionals and students in talking about DDB. ${ }^{3} 4$ Case studies from the distant and recent past, across cultures and geographical space, were used in themed workshops facilitating participants to reflect on and discuss memorialisation, legacy, age and circumstance of death, images of the dead, ancestors, place, treatment of the dead and objects. The impact of the workshops has been evaluated using a number of methods including discussion with participants as to what they did as a consequence of attending a workshop. As an illustration of the impact that is emerging we share here one specific outcome: a poem that one participant wrote as a consequence of attending a workshop and the continued impact on his thinking.

In an Ancestors-themed workshop, there was group discussion about what people wanted for themselves after death-to be buried or cremated. In a later interview, the participant explained that the deaths of loved ones had prompted him to train in counselling and psychotherapy, his client load including bereaved individuals. The workshop came as he was practising psychotherapy and shortly after another bereavement. The participant explained that the Ancestors workshop discussion inspired him to write a poem Funeral Plan which is showcased below.

Writing poetry can be an act of reflection and has therapeutic benefits. ${ }^{5}$ Through poetry, we think about a particular subject and mull over what it means to us. When we commit it to paper we might do so to record our musings and, in some cases, to communicate them to others. In his postworkshop interview, the participant described musing about and reflecting on his funeral, 'Every now and then I get mildly interested in planning how it'll [his funeral will] be and then I think, actually it's not for me, it's not for me at all. This is for the people who are left behind.' This sentiment is explored in Funeral Plan.

This poem, its author and the Continuing Bonds evaluation ${ }^{3} 4$ more broadly evidence that interacting with archaeology can spark communication, reflection and interactive activities about DDB. The impact of such workshops can be profound for the individual in both their personal consideration of mortality and loss and in their professional interactions with patients and clients.

Funeral Plan is published by kind permission of the author, Peter Wakefield. Permission to publish this article and poem, along with the name of the poet, was sought before submission.

\section{Funeral Plan}

As for me, I do not plan to attend -

You may do as you please, do as you need.

I had many thoughts about the music,

Too many notes it turned out in the end -

Could not prune it to a de-

sert-island eight

Let alone a quartet to celebrate The life I led, the man I used to be.

Wesley or Dylan? Up to you, not me.

Food is usual but I'll not cook today A massive spread or just the tea and scones
With which we said farewell to Lesley?

I shall have no appetite either way.

Free to drink like the proverbial fish

Untrammelled by my poorly-hidden wish

That you might take it easy with the gin;

"Pissed at a wake" hardly

counts as sin.

Is God invited or is She out of luck?

My mixed feelings will be settled now

But I'm glad it's not my call to make;

Everyone else is in the address book.

Have what fun you can, the room will be full

With stories, laughter, tears, someone on the pull

For life goes on at funerals too

But now I must leave all of that to you.

-Peter Wakefield

Jennifer Ellen Dayes, ${ }^{1}$ Christina Faull, ${ }^{2}$ Lindsey Büster, ${ }^{1}$ Laura Iraine Green, ${ }^{3}$ Karina Croucher ${ }^{1}$

${ }^{1}$ Department of Archaeological and Forensic Sciences, University of Bradford, Bradford, UK ${ }^{2}$ LOROS Hospice, Leicester, UK

${ }^{3}$ Faculty of Health Sciences, University of Bradford, Bradford, UK

Correspondence to Dr Jennifer Ellen Dayes, Department of Archaeological and Forensic Sciences, University of Bradford, Bradford BD7 1DP, UK; j.dayes@bradford.ac.uk

Contributors JED wrote the poem up for publication. CF, KC and LB gave feedback on the draft and contributed to its content. KC, CF, LB, JED and LIG all contributed to the planning and conducting of the study, including the workshops from which the poem arose.

Funding This study was funded by the Arts and Humanities Research Council (Grant No AH/M008266/1). 
Competing interests All authors are funded by the Arts and Humanities Research Council Continuing Bonds Project.

Patient consent Not required.

Ethics approval The Continuing Bonds Project has been granted ethical approval by the University of Bradford's Internal Ethics Committee and the Health

Research Authority (NIHR No203842).

Provenance and peer review Not commissioned; internally peer reviewed.

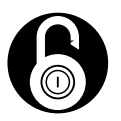

\section{OPEN ACCESS}

Open access This is an open access article distributed in accordance with the Creative Commons Attribution Non Commercial (CC BY-NC 4.0) license, which permits others to distribute, remix, adapt, build upon this work noncommercially, and license their derivative works on different terms, provided the original work is properly cited, appropriate credit is given, any changes made indicated, and the use is noncommercial. See: http://creativecommons. org/licenses/by-nc/4.0/

(C) Author(s) (or their employer(s)) 2019. Re-use permitted under CC BY-NC. No commercial re-use. See rights and permissions. Published by BMJ.

\section{(A) Check for updates}

To cite Dayes JE, Faull C, Büster L, et al. BMJ Supportive \& Palliative Care 2019;9:229-230.

Received 9 April 2018

Revised 17 July 2018

Accepted 8 August 2018

Published Online First 22 September 2018

\section{REFERENCES}

1 Grubb C, Arthur A. Student nurses' experience of and attitudes towards care of the dying: a cross-sectional study. Palliat Med 2016;30:83-8.

2 Henoch I, Melin-Johansson C, Bergh I, et al. Undergraduate nursing students' attitudes and preparedness toward caring for dying persons - a longitudinal study. Nurse Educ Pract 2017;26:12-20.

3 Croucher K, Faull C, Green L. What value and contribution can archaeology give to end-of-life practitioners? $B M J$ Support Palliat Care 2018;8:A6.

4 Büster L, Croucher K, Dayes J, et al. From plastered skulls to palliative care: what the past can teach us about dealing with death. In Press.

5 Soter AO. Reading and writing poetically for well-being: language as a field of energy in practice. Journal of Poetry Therapy 2016;29:161-74. 